\section{ANALISIS PERHITUNGAN, PENCATATAN, PENYETORAN DAN PELAPORAN PAJAK PENGHASILAN 21 PADA RS VANIA BOGOR TAHUN 2015-2016}

\author{
Yudha Pratama Prihatono dan Hadi Sutomo \\ Program Studi Akuntansi, Institut Bisnis dan Informatika Kesatuan \\ Bogor, Indonesia \\ Email :lemlit@stiekesatuan.ac.id
}

\author{
Analisis \\ Perhitungan, \\ Pencatatan, \\ Penyetoran dan \\ Pelaporan \\ Pajak \\ Penghasilan 21 \\ Pada RS Vania \\ Bogor Tahun \\ 2015 - 2016
}

\section{1}

Keywords: $\quad$ Article 21 Income Tax, PER 32 / PJ /2015, PER 16 / PJ /2016, qualitative descriptive

\section{PENDAHULUAN}

Indonesia saat ini sedang berupaya meningkatkan kesejahteraan masyarakat dan pembangunan nasional di bidang kesehatan, pembangunan infrastruktur, pendidikan, dan pembangunan fasilitas publik. Dalam meningkatkan kesejahteraan dan pembangunan nasional tersebut pajak merupakan salah satu penerimaan negara yang diperlukan. Hal ini dikarenakan pajak sebagai sumber penerimaan negara yang digunakan untuk membiayai pengeluaran pemerintah dan pembangunan nasional. Dalam pelaksanaannya pemerintah mendorong masyarakat agar ikut berpartisipasi secara aktif dalam program pemenuhan hak dan kewajiban perpajakan. Wajib Pajak harus dapat memahami tata cara pemenuhan kewajiban perpajakan yang diatur daam peraturan perpajakan yang berlaku di Indonesia. Hal ini sejalan dengan sistem perpajakan Indonesia yang menganut self assessment system.

\footnotetext{
JIAKES

Jurnal Ilmiah Akuntansi Vol. 7 No 2, 2019 pg. $331-342$ IBI Kesatuan Kesatuan
2337- 7852
} MEI 2019 Accepted: OKTOBER 2019

\begin{abstract}
This research was conducted at Vania Bogor Hospital which is located at Jalan Siliwangi No.42, Sukasari, Bogor Timur, Kota Bogor, West Java 16142. The purpose of this study was to find out the Suitability of Calculation, Deposit and Reporting at Vania Bogor Hospital in 2015-2016 by Regulation The Director of Tax as stated in PER 32 / PJ / 2015 and PER 16 / PJ / 2016 and Knowing the Suitability of Recordings conducted by Vania Bogor Hospital with generally accepted Accounting Standards.

This research is a qualitative research with a descriptive approach. This method is used with the aim to answer and provide an overview of the analysis of calculation, recording, depositing and reporting PPh Article 21. The analysis method used by the writer is descriptive qualitative writing, which is an attempt to collect and compile a data, then analyze the data . Descriptive analysis is the data collected is in the form of numbers.

The results of the research show that the calculation, recording, depositing and reporting conducted by Vania Bogor Hospital is in accordance with the generally accepted tax regulations and accounting standards. However, there are some SPT for Correction Periods in Reporting that were carried out by Vania Bogor Hospital which was caused by being wrong in calculating the number of employees. For Vania Bogor Hospital employees who are responsible for Article $21 \mathrm{PPh}$, it is advisable to do the right calculation between the number of employees who are still working and the number of employees who are no longer working at Vania Bogor Hospital.

ABSTRACT
\end{abstract}


Analisis

Perhitungan,

Pencatatan,

Penyetoran dan

Pelaporan Pajak

Penghasilan 21

Pada RS Vania

Bogor Tahun

$2015-2016$

Salah satu bentuk penerapan self assessment system adalah terkait dengan pemenuhan kewajiban Pajak Penghasilan Pasal 21 atau yang lebih dikenal dengan PPh Pasal 21 dimana wajib pajak diberikan kebebasan untuk menghitung dan menentukan sendiri jumlah pajak penghasilan pasal 21 terutangnya. Dalam pelaksanaannya $\mathrm{PPh}$ Pasal 21 temasuk dalam kategori withholding system atau PPh potong pungut hal ini dikarenakan dalam proses pemungutannya melibatkan pihak ke tiga yaitu pemberi kerja untuk melaksanakan kewajiban memotong atau memungut pajak atas penghasilan yang dibayarkan kepada penerima penghasilan sekaligus menyetor ke kas negara.

Pihak-pihak pemberi kerja yang wajib memotong atau memungut PPh Pasal 21 adalah bendaharawan (lembaga pemerintah), wajib pajak dalam negeri, penyelenggara kegiatan, bentuk usaha tetap, perwakilan perusahaan luar negeri lainnya, dan wajib pajak orang pribadi dalam negeri tertentu yang ditujukan oleh Direktorat Jenderal Pajak. Pihak yang menerima penghasilan yang dipotong PPh Pasal 21 adalah wajib pajak dalam negeri (WPDN) dan bentuk usaha tetap (BUT).

Menurut Peraturan Direktur Jenderal Pajak Nomor PER-16/PJ/2016, Pajak Penghasilan Pasal 21 adalah pajak atas penghasilan berupa gaji, upah, honorarium, tunjangan dan pembayaran lain dengan nama dan dalam bentuk apa pun sehubungan dengan pekerjaan atau jabatan jasa, dan kegiatan yang dilakukan oleh orang pribadi subyek pajak dalam negeri.

Perubahan terhadap peraturan perpajakan yang sering dilakukan oleh dirjen Pajak menunjukkan sangat dinamisnya peraturan perpajakan dan hal ini dapat berdampak terhadap hasil perhitungan pajak. Berkaitan dengan PPh Pasal 21, hal yang sering terjadi perubahan adalah Penghasilan Tidak Kena Pajak (PTKP). Hal ini bisa dibuktikan didalam kurun waktu tahun 2015 ke 2016 terjadi setidaknya 2 kali perubahan PTKP yaitu untuk PTKP tahun 2015 dan 2016 pada awalnya mengacu pada Peraturan Direktur Jenderal Pajak Nomor : PER-32/PJ/2015 namun pada pertengahan tahun 2016 terdapat perubahan PTKP melalui Peraturan Menteri Keuangan Nomor101/PMK.010/2016 dan 102/PMK.010/2016 serta Peraturan Direktur Jenderal Pajak Nomor: PER 16/PJ/2016 yang berlaku surut sejak Januari 2016. Perubahan PTKP yang terjadi di pertengahan tahun dapat menimbulkan terjadinya kesalahan dalam menghitung $\mathrm{PPh}$ Pasal 21 apabila pihak perusahaan tidak segera melakukan penyesuaian, sehingga hal ini dapat menimbulkan terjadinya kelebihan pembayaran $\mathrm{PPh}$ Pasal 21 ke negara dan kelebihan pemotongan PPh Pasal 21 kepada karyawan.

Berikut Perubahan PTKP sebagaimana telah dijelaskan pada peraturan perpajakan yaitu PER 32/PJ/2015 dan PER 16/PJ/2016:

Tabel 1. Perubahan PTKP Per Tahun

\begin{tabular}{|c|c|c|}
\hline STATUS & $\begin{array}{c}2015 \\
(\mathrm{PER} 32 / \mathrm{PJ} / 2105)\end{array}$ & $\begin{array}{c}2016 \\
(\mathrm{PER}-16 / \mathrm{PJ} / 2016)\end{array}$ \\
\hline $\mathrm{TK} / 0$ & Rp 36.000.000 & Rp 54.000.000 \\
\hline $\mathrm{TK} / 1$ & Rp 39.000.000 & Rp 58.500.000 \\
\hline $\mathrm{TK} / 2$ & $\operatorname{Rp} 42.000 .000$ & Rp 63.000.000 \\
\hline $\mathrm{TK} / 3$ & Rp 45.000.000 & $\operatorname{Rp} 67.500 .000$ \\
\hline $\mathrm{K} / 0$ & Rp 39.000.000 & Rp 58.500.000 \\
\hline
\end{tabular}




\begin{tabular}{|l|l|l|}
\hline $\mathrm{K} / 1$ & $\operatorname{Rp} 42.000 .000$ & $\operatorname{Rp} 63.000 .000$ \\
\hline $\mathrm{K} / 2$ & $\operatorname{Rp} 45.000 .000$ & $\operatorname{Rp} 67.500 .000$ \\
\hline $\mathrm{K} / 3$ & $\mathrm{Rp} 48.000 .000$ & $\operatorname{Rp} 72.000 .000$ \\
\hline
\end{tabular}

Sumber: PER-32/PJ/2015 \& PER-16/PJ/2016, 2018

Selain dari permasalahan perubahan PTKP itu sendiri, perusahaan sering kali melakukan kesalahan dalam melakukan perhitungan $\mathrm{PPh} 21$, yang disebabkan kurang terampilnya karyawan bagian pajak perusahaan yang menangani PPh Pasal 21 dalam melakukan perhitungan, akibat tidak sampainya informasi dan kurangnya pemahaman yang benar terhadap teknis perhitungan PPh Pasal 21, sehingga perhitungan pajak menjadi tidak benar yaitu tidak sesuai dengan ketentuan perpajakan yang berlaku yang dapat menimbulkan resiko terjadinya sanksi perpajakan sebagai akibat karena tidak lapor, terlambat lapor dan setor dan kurang bayar. Terkait teknis menghitung PPh Pasal 21 sangat diperlukan keterampilan khusus untuk menghindari terjadinya kesalahan dalam menghitung pajak, mengingat banyaknya teknis perhitungan PPh Pasal 21, hal ini dikarenakan teknis perhitungan PPh Pasal 21 tidak semata-mata dilihat dari jenis penghasilannya, namun juga dilihat dari sifat penghasilan serta subyek penerima penghasilan. Semakin beragam jenis sifat maupun subyek penerima penghasilan pada suatu perusahaan maka akan sangat semakin beragam teknis perhitungan PPh Pasal 21 sebagai contoh di Rumah sakit. Dalam Rumah Sakit terdapat berbagai macam karyawan, seperti dokter sebagai tenaga ahli, perawat, karyawan bagian administrasi, karyawan bagian akuntansi, karyawan bagian HRD dan sebagainya.

Berdasarkan uraian dan latar belakang tersebut, dirasakan perlu untuk melakukan penelitian yang terkait dengan : Analisis Perhitungan, Pencatatan, Penyetoran dan Pelaporan Pajak Penghasilan Pasal 21pada RS Vania Bogor Tahun 2015-2016.

\section{TINJAUAN PUSTAKA}

Menurut Mardiasmo (2013, 2) "Pajak Penghasilan 21 adalah pajak atas penghasilan berupa gaji, upah, honorarium, tunjangan dan pembayaran lain dengan nama dan dalam bentuk apapun sehubungan dengan pekerjaan atau jabatan, jasa dan kegiatan yang dilakukan oleh orang pribadi”.

Menurut Waluyo $(2016,244)$ "Pajak Penghasilan Pasal 21 merupakan Pajak Penghasilan yang dikarenakan atas penghasilan yang berupa gaji, upah, honorarium, tunjangan dan pembayaran lain dengan bentuk dan nama apa pun yang diterima atau diperoleh Wajib Pajak Orang Pribadi dalam negeri sehubungan dengan pekerjaan, jasa atau kegiatan tersebut yang dilakukan oleh Wajib Pajak Orang Pribadi dalam negeri”.

Dalam Peraturan Direktorat Jenderal Pajak Nomor PER-/16/PJ/2016, Pajak Penghasilan Pasal 21 adalah pajak atas penghasilan berupa gaji, upah, honorarium, tunjangan dan pembayaran lain dengan nama dan dalam bentuk apa pun sehubungan dengan pekerjaan atau jabatan, jasa, dan kegiatan yang dilakukan oleh orang pribadi subyek pajak dalam negeri. Dapat disimpulkan bahwa Pajak Penghasilan Pasal 21 atas penghasilan karyawan yang jumlah pajaknya langsung dipotong oleh pemberi kerja. 
Dasar hukum PPh Pasal 21 adalah:

Analisis

Perhitungan,

Pencatatan,

Penyetoran dan

Pelaporan Pajak

Penghasilan 21

Pada RS Vania

Bogor Tahun

2015 - 2016

1. Peraturan Direktorat Jenderal Pajak Nomor PER-32/PJ/2015 tentang Pedoman Teknis Tata Cara Pemotongan, Penyetoran dan Pelaporan Pajak Penghasilan Pasal 21 dan/atau Pajak Penghasilan yang sehubungan dengan pekerjaan, jasa, dan kegiatan orang pribadi sebagaimana yang telah diubah dengan Peraturan Direktur Jenderal Pajak Nomor PER-16/PJ/2016.

2. PP 28 Tahun 2015 tentang Kedudukan. Tugas dan fungsi Ditjen Pembendaharaan dalam Pengelolaan Anggaran Pendapatan dan Belanja Negara.

3. Gaji Pegawai Negeri Sipil (PNS) 2015-2017 berdasarkan Peraturan Pemerintah Nomor 30 Tahun 2015 tentang Perubahan Ketujuh Belas Atas Peraturan Pemerintah nomor 7 tahun 1977 mengenai gaji pegawai negeri sipil

4. Perdirjen Nomor Per-03/PB/2015 tentang Perubahan Kelima Atas PeraturanDirektur Jenderal Perbendaharaan tentang Perubahan kelima atas PeraturanDirektur Jenderal Perbendaharaan Nomor PER-67/PB/2010 tentang TunjanganBeras dalam Bentuk Natura dan Uang.

5. PP No.80 Tahun 2010 tentang Tarif Pemotongan dan Pengenaan PajakPenghasilan Pasal 21 atas penghasilan yang menjadi beban Anggran Pendapatandan Belanja Negara atau Anggaran pendapatan dan Belanja Daerah.

\section{METODE PENELITIAN}

Dalam penelitian ini metode yang digunakan adalah deskriptif kualitatif. Metode ini digunakan dengan tujuan untuk menjawab serta memberikan gambaran mengenai analisis perhitungan, pencatatan, penyetoran dan pelaporan $\mathrm{PPh}$ Pasal 21 Jenis dan sumber data yang digunakan oleh penulis dalam penelitian ini adalah:

1. Data primer merupakan sumber data yang diperoleh secara langsung dari sumber asli (tidak melalui media perantara). Dalam penelitian ini, data diperoleh dengan cara mengadakan observasi, wawancara langsung dengan pimpinan perusahaan serta sejumlah karyawan pada RS Vania Bogor.

2. Data sekunder merupakan sumber data penelitian yang diperoleh peneliti secara tidak langsung melalui media perantara (diperoleh dan dicatat pihak lain). Seperti contoh yaitu; data sejarah perusahaan yang diambil dari situs/website Official RS Vania Bogor

Metode pengumpulan data yang digunakan adalah sebagai berikut.

a. Penelitian Lapangan (Field Research)

1. Observasi, yakni pengumpulan data yang dilakukan dengan mengadakan pengamatan secara langsung ke objek penelitian, tepatnya pada RS Vania Bogor.

2. Interview, yaitu bentuk pengumpulan data yang dilakukan dengan mengadakan wawancara atau tatap muka secara langsung dengan pimpinan perusahaan dan staf personil yang ada kaitannya dengan masalah penelitian yang akan dibahas. 
3. Dokumentasi, yakni pengumpulan data yang dilakukan dengan jalan mengumpulkan dokumen-dokumen perusahaan yang relevan dengan masalah penelitian yang akan dibahas.

b. Penelitian Pustaka (Library Research) Metode ini merupakan bentuk pengumpulan data yang dilakukan dengan mempelajari literatur-literatur, karyakarya ilmiah, serta bacaan-bacaan lain yang berkaitan dengan penelitian.

Untuk mengolah data penelitian ini, digunakan beberapa metode analisis, yaitu:

a. Metode analisis deskriptif yaitu usaha untuk mengumpulkan dan menyusun suatu data, kemudian dilakukan analisis terhadap data tersebut. Analisis deskriptif yakni data yang dikumpulkan adalah berupa angkaangka. Hal ini disebabkan oleh adanya penerapan metode kuantitatif. Selain itu, semua yang dikumpulkan berkemungkinan menjadi kunci terhadap apa yang sudah diteliti. Dengan demikian laporan penelitian akan berisi pengolahan data untuk memberi gambaran penyajian laporan tersebut.

b. Analisis komparatif (perbandingan), di mana analisis ini membandingkan pajak penghasilan pasal 21 yang diterapkan di RS Vania Bogor dengan Undang-Undang Nomor 36 Tahun 2008.

\section{HASIL DAN PEMBAHASAN}

Penelitian ini dibatasi hanya terkait dengan perhitungan, pencatatan, penyetoran dan pelaporan PPh Pasal 21, dengan periode penelitian dari tahun 2015 dan tahun 2016. Proses penelitian dilakukan melalui metode wawancara dan analisis dokumentasi. Wawancara telah dilakukan dengan pihak rumah sakit yang diwakili oleh pegawai bagian HRD yang menangani bidang penggajian dan bagian akuntansi. Sedangkan analisis dokumen dilakukan dengan membaca dan memahami dokumen SPT Masa PPh pasal 21 dari tahun 2015 dan 2016.

Proses wawancara dilakukan dalam rangka untuk mengetahui informasi terkait struktur kepegawaian dan sistem penggajian yang berlaku di RS Vania Bogor. Informasi mengenai struktur kepegawaian sangat penting terutama untuk mengetahui status kepegawaian seperti status pegawai tetap dan pegawai tidak tetap, pegawai dan bukan pegawai, sebab status pegawai tersebut akan berpengaruh terhadap mekanisme perhitungan PPh Pasal 21. Status kepegawaian ini sangat penting untuk diketahui karena berkaitan dengan mekanisme perhitungan PPh Pasal 21. Kemudian informasi mengenai sistem penggajian sangat penting untuk diketahui karena berkaitan dengan mekanisme perhitungan PPh Pasal 21 sebab sistem penggajian secara bulanan, mingguan dan harian tentu memiliki perbedaan dalam tata cara menghitung PPh Pasal 21 terutang dan akan mempengaruhi sistem pencatatan secara akuntansi.

Struktur kepegawaian yang ada di RS Vania Bogor terdiri dari seorang Direktur Umum yang membawahi tiga orang Manajer yaitu Manajer Umum, Manajer Penunjang Medis, dan Manajer Medis. Manajer Umum membawahi divisi keuangan, 
Analisis

Perhitungan,

Pencatatan,

Penyetoran dan

Pelaporan Pajak

Penghasilan 21

Pada RS Vania

Bogor Tahun

$2015-2016$

divisi pemasaran, administrasi dll. Kemudian Manajer Penunjang Medis membawahi Pegawai Lab dan Pegawai Radiologi. Manajer Medis membawahi Dokter Spesialis, Bidan, Perawat. Status kepegawaian yang ada di RS Vania Bogor terdiri dari 2 jenis yaitu, Pegawai dengan status PKWT (Perjanjian Kerja Waktu Tertentu) atau yang biasa disebut Pegawai Kontrak dan Pegawai dengan status PKWTT (Perjanjian Kerja Waktu Tidak Tertentu) atau yang biasa disebut pegawai tetap. Selain itu ada pembayaran upah yang dilaksanakan kepada bukan pegawai. Sistem penggajian di RS Vania Bogor yang berlaku selama periode penelitian adalah sistem penggajian yang dilakukan secara bulanan.

\section{Perhitungan PPh Pasal 21 pada RS Vania Bogor}

a. Pegawai Tetap

Pelaksanaan Perhitungan PPh Pasal 21 terhadap Dr. Greson Abrahams telah sesuai dengan Peraturan Direktorat Jenderal Pajak yang tercantum dalam PER 32/PJ/2015. Dimulai dari PTKP per tahunnya yaitu sebesar Rp 42.000 .000 (K/1). Ini sudah sesuai dengan yang tertera pada Peraturan Dirjen Pajak yakni tarif untuk K/1 per tahun yaitu sebesar Rp 42.000.000. Lalu perhitungan untuk tunjangan seperti BPJS Kes dan BPJS TK juga sesuai dengan peraturan yang berlaku. Tabel 1 akan menjelaskan kesesuaian perhitungan PPh Pasal 21 atas dr. Greson Abrahams dengan Peraturan Perpajakan selama tahun 2015:

Tabel 1

Kesesuaian Perhitungan PPh Pasal 21 atas dr. Greson Abrahams Tahun 2015

\begin{tabular}{|c|c|c|c|c|}
\hline \multirow{2}{*}{$\begin{array}{c}\text { Penghasilan } \\
\text { Bruto }\end{array}$} & \multicolumn{2}{|c|}{ Jumlah (Rp) } & \multirow{2}{*}{ Selisih } & \multirow{2}{*}{ Kesesuaian } \\
\hline & Rumah Sakit & Peraturan & & \\
\hline Gaji Pokok & 180.000 .000 & 180.000 .000 & -- & Sesuai \\
\hline BPJS Kes & 7.200 .000 & 7.200 .000 & -- & Sesuai \\
\hline JKK & 432.000 & 432.000 & -- & Sesuai \\
\hline JKM & 540.000 & 540.000 & -- & Sesuai \\
\hline Tunj. Koor & 3.600 .000 & 3.600 .000 & -- & Sesuai \\
\hline Tunj lain2 & 9.000 .000 & 9.000 .000 & -- & Sesuai \\
\hline $\begin{array}{l}\text { Jmlh } \\
\text { penghasilan } \\
\text { bruto }\end{array}$ & 200.772 .000 & 200.772 .000 & -- & Sesuai \\
\hline \multicolumn{5}{|l|}{ Pengurang } \\
\hline Biaya Jabatan & 6.000 .000 & 6.000 .000 & -- & Sesuai \\
\hline Iuran JHT & 4.015 .440 & 4.015 .440 & -- & Sesuai \\
\hline \multicolumn{5}{|c|}{ Penghitungan PPh Pasal 21} \\
\hline $\begin{array}{l}\text { Jumlah } \\
\text { Penghasilan } \\
\text { Netto }\end{array}$ & 190.756 .560 & 190.756 .560 & -- & Sesuai \\
\hline PTKP $(\mathrm{TK} / 0)$ & 42.000 .000 & 42.000 .000 & -- & Sesuai \\
\hline PKP & 148.750 .560 & 148.750 .560 & -- & Sesuai \\
\hline PPh Pasal 21 & 17.313 .489 & 17.313 .489 & -- & Sesuai \\
\hline
\end{tabular}


terutang

Sumber: Bukti Pemotongan PPh Pasal 21, Data diolah

b. Pegawai Tidak Tetap

Perhitungan PPh Pasal 21 terhadap Asmarida telah sesuai dengan Peraturan Dirjen Pajak: PER 16/PJ/2016. Format perhitungan PPh Pasal 21 sama dengan pegawai tetap dikarenakan sistem penggajian terhadap Asmarida dilakukan secara bulanan. Tabel 2 akan menjelaskan kesesuaian perhitungan PPh Pasal 21 atas Asmarida dengan Peraturan Perpajakan selama tahun 2016:

Tabel 4.2

Analisis

Perhitungan,

Pencatatan,

Penyetoran dan

Pelaporan Pajak

Penghasilan 21

Pada RS Vania

Bogor Tahun

2015 - 2016

Kesesuaian Perhitungan PPh Pasal 21 atas Asmarida Tahun 2016

\begin{tabular}{|c|c|c|c|c|}
\hline \multirow{2}{*}{$\begin{array}{c}\text { Penghasilan } \\
\text { Bruto }\end{array}$} & \multicolumn{2}{|c|}{ Jumlah (Rp) } & \multirow{2}{*}{ Selisih } & \multirow{2}{*}{ Kesesuaiar } \\
\hline & Rumah Sakit & Peraturan & & \\
\hline Gaji Pokok & 84.000 .000 & 84.000 .000 & -- & Sesuai \\
\hline BPJS Kes & 3.360 .000 & 3.360 .000 & -- & Sesuai \\
\hline JKK & 201.600 & 201.600 & -- & Sesuai \\
\hline JKM & 252.000 & 252.000 & -- & Sesuai \\
\hline Tunj lain2 & 9.000 .000 & 9.000 .000 & -- & Sesuai \\
\hline $\begin{array}{l}\text { Jmlh } \\
\text { penghasilan } \\
\text { bruto }\end{array}$ & 96.813 .600 & 96.813 .600 & -- & Sesuai \\
\hline \multicolumn{5}{|l|}{ Pengurang } \\
\hline Biaya Jabatan & 4.840 .680 & 4.840 .680 & -- & Sesuai \\
\hline Iuran JHT & 1.936 .272 & 1.936 .272 & -- & Sesuai \\
\hline \multicolumn{5}{|c|}{ Penghitungan PPh Pasal 21} \\
\hline $\begin{array}{l}\text { Jumlah } \\
\text { Penghasilan } \\
\text { Netto }\end{array}$ & 90.036 .648 & 90.036 .648 & -- & Sesuai \\
\hline PTKP $(\mathrm{TK} / 0)$ & 54.000 .000 & 54.000 .000 & -- & Sesuai \\
\hline PKP & 36.036 .648 & 36.036 .648 & -- & Sesuai \\
\hline $\begin{array}{l}\text { PPh Pasal } 21 \\
\text { terutang }\end{array}$ & 1.801 .832 & 1.801 .832 & -- & Sesuai \\
\hline
\end{tabular}

Sumber: Bukti Pemotongan PPh 21 RS Vania Bogor, Data diolah

c. Bukan Pegawai yang bersifat Berkesinambungan

Selanjutnya yaitu perhitungan PPh Pasal 21 terhadap Tenaga Ahli yang bersifat berkesinambungan. Yang dimaksud tenaga ahli disini yaitu yang menerima penghasilan sehubungan dengan pemberian jasa. Sampel yang saya gunakan di rumah sakit yaitu Tenaga Ahli Dokter. Pada sampel pertama, penulis melakukan analisis terhadap perhitungan PPh pasal 21 terhadap Dr. Andreaw Pranolo, Sp.S yang menjabat sebagai 
Analisis

Perhitungan,

Pencatatan,

Penyetoran dan

Pelaporan Pajak

Penghasilan 21

Pada RS Vania

Bogor Tahun

$2015-2016$ seorang dokter spesialis saraf. Selain praktik di RS Vania Bogor dr. Andreaw Pranolo,Sp.S juga melakukan praktik sendiri di klinik pribadinya. dr. Andreaw Pranolo,Sp.S telah memiliki NPWP. Berikut ini adalah perhitungan PPh Pasal 21 atas Tenaga Ahli yang sesuai dengan PER-32/PJ/2015, dimana untuk menentukan yaitu (Penghasilan Bruto Awal x 50\%) $=*$ dasar pemotongan $\mathrm{x}$ Tarif $\mathrm{PPh} 5 \%$ ) lalu untuk periode bulan kedua dan berikutnya adalah (Penghasilan Bruto x 50\% lalu hasilnya + *dasar pemotongan bulan sebelumnya untuk menentukan tarif $\mathrm{PPh}$ nya dimana hasil dari perkalian bruto akan dikalikan kembali dengan tarif PPh sesuai dengan dasar pemotongan kumulatif) dan perhitungan kumulatif tersebut dilanjutkan ke periode berikutnya. Berikut ini adalah kesesuaian Perhitungan PPh Pasal 21 atas dr. Andreaw Pranolo yang dilaksanakan RS Vania Bogor dengan PER-32/PJ/2015.

Tabel 4.3

Kesesuaian Perhitungan PPh Pasal 21 atas dr. Andreaw Pranolo Tahun 2015

\begin{tabular}{|c|c|c|c|c|c|}
\hline \multirow[b]{2}{*}{ Bulan } & \multirow{2}{*}{$\begin{array}{l}\text { Penghasil } \\
\text { an Bruto }\end{array}$} & \multicolumn{2}{|c|}{ PPh Pasal 21 terutang } & \multirow{2}{*}{$\begin{array}{c}\text { Selisi } \\
\mathbf{h}\end{array}$} & \multirow[b]{2}{*}{$\begin{array}{l}\text { Keses } \\
\text { uaian }\end{array}$} \\
\hline & & $\begin{array}{c}\text { Rumah } \\
\text { Sakit }\end{array}$ & Peraturan & & \\
\hline Januari & $\begin{array}{c}20.000 .00 \\
0\end{array}$ & 500.000 & 500.000 & -- & Sesuai \\
\hline $\begin{array}{l}\text { Februar } \\
\text { i }\end{array}$ & $\begin{array}{c}15.000 .00 \\
0\end{array}$ & 375.000 & 375.000 & -- & Sesuai \\
\hline Maret & $\begin{array}{c}16.000 .00 \\
0\end{array}$ & 400.000 & 400.000 & -- & Sesuai \\
\hline April & $\begin{array}{c}10.000 .00 \\
0\end{array}$ & 250.000 & 250.000 & -- & Sesuai \\
\hline Mei & $\begin{array}{c}20.000 .00 \\
0\end{array}$ & 500.000 & 500.000 & -- & Sesuai \\
\hline Juni & $\begin{array}{c}17.000 .00 \\
0\end{array}$ & 425.000 & 425.000 & -- & Sesuai \\
\hline Juli & $\begin{array}{c}13.000 .00 \\
0\end{array}$ & 875.000 & 875.000 & -- & Sesuai \\
\hline Agustus & $\begin{array}{c}15.000 .00 \\
0\end{array}$ & 1.125 .000 & 1.125 .000 & -- & Sesuai \\
\hline $\begin{array}{l}\text { Septem } \\
\text { ber }\end{array}$ & $\begin{array}{c}15.000 .00 \\
0\end{array}$ & 1.125 .000 & 1.125 .000 & -- & Sesuai \\
\hline Oktober & $\begin{array}{c}16.000 .00 \\
0\end{array}$ & 1.200 .000 & 1.200 .000 & -- & Sesuai \\
\hline $\begin{array}{l}\text { Nopem } \\
\text { ber }\end{array}$ & $\begin{array}{c}14.000 .00 \\
0\end{array}$ & 1.050 .000 & 1.050 .000 & -- & Sesuai \\
\hline $\begin{array}{l}\text { Desemb } \\
\text { er }\end{array}$ & $\begin{array}{c}15.000 .00 \\
0\end{array}$ & 1.125 .000 & 1.125 .000 & -- & Sesuai \\
\hline
\end{tabular}

Sumber: Bukti Pemotongan PPh Pasal 21 RS Vania Bogor, Data Diolah 
Berdasarkan Tabel 3 perhitungan PPh Pasal 21 atas Tenaga Ahli yang dilaksanakan RS Vania Bogor untuk bulan Januari sampai dengan Desember telah sesuai dengan PER-32/PJ/2015.

d. Bukan Pegawai yang tidak Bersifat Berkesinambungan

Dilakukan juga analisis terhadap dr. Dian Mustikawati, Sp.M seorang dokter spesialis mata.Pada Tahun 2016, dr. Dian Mustikawati mendapatkan fee pada Bulan Juli atas jasa yang dilakukan. Untuk perhitungan PPh Pasal 21 yaitu (50\% x 5\% x jumlah penghasilan bruto). Perhitungan PPh pasal 21 yang dilakukan oleh RS Vania Bogor atas dr. Dian Mustikawati, Sp.M telah sesuai dengan Peraturan Dirjen Pajak PER $16 / \mathrm{PJ} / 2016$.

2. Pencatatan PPh Pasal 21 Pada RS Vania Bogor

Analisis

Perhitungan,

Pencatatan,

Penyetoran dan

Pelaporan Pajak

Penghasilan 21

Pada RS Vania

Bogor Tahun

2015 - 2016

Tabel 4

Kesesuaian Pencatatan PPh Pasal 21 pada Tahun 2015

\begin{tabular}{|c|c|c|}
\hline Date & Menurut Perusahaan & Menurut Standar Akuntansi \\
\hline \multirow{14}{*}{$\begin{array}{c}\text { Januari } \\
2015\end{array}$} & \multicolumn{2}{|c|}{$\begin{array}{c}\text { Saat Pembayaran Gaji } \\
\text { Pegawai Tetap }\end{array}$} \\
\hline & B.Gaji 260.993 .881 & B.Gaji $\quad 260.993 .881$ \\
\hline & Utang PPh $21 \quad 3.521 .700$ & Utang PPh $21 \quad 3.521 .700$ \\
\hline & Bank $\quad 257.472 .181$ & Bank $\quad 257.472 .181$ \\
\hline & \multicolumn{2}{|c|}{ Saat Pembayaran PPh 21} \\
\hline & B.PPh $21 \quad 3.521 .700$ & B.PPh $21 \quad 3.521 .700$ \\
\hline & Bank $\quad 3.521 .700$ & 3.521 .700 \\
\hline & \multicolumn{2}{|c|}{$\begin{array}{c}\text { Saat Pembayaran Gaji } \\
\text { Tenaga Ahli }\end{array}$} \\
\hline & B.Dokter165.475.876 & B.Dokter165.475.876 \\
\hline & Utang PPh $21 \quad 4.211 .897$ & Utang PPh $21 \quad 4.211 .897$ \\
\hline & Bank $\quad 161.263 .979$ & Bank $\quad 161.263 .979$ \\
\hline & \multicolumn{2}{|c|}{$\begin{array}{l}\text { Saat Pembayaran PPh } 21 \\
\end{array}$} \\
\hline & B.PPh $21 \quad 4.211 .897$ & B.PPh $21 \quad 4.211 .897$ \\
\hline & Bank $\quad 4.211 .897$ & Bank $\quad 4.211 .897$ \\
\hline \multirow{15}{*}{$\begin{array}{l}\text { Desember } \\
2015\end{array}$} & \multicolumn{2}{|c|}{$\begin{array}{c}\text { Saat Pembayaran Gaji } \\
\text { Pegawai Tetap }\end{array}$} \\
\hline & B.Gaji $\quad 384.006 .871$ & B.Gaji $\quad 384.006 .871$ \\
\hline & Utang PPh $21 \quad 5.840 .471$ & Utang PPh $21 \quad 5.840 .471$ \\
\hline & 378.166 .399 & 378.166 .399 \\
\hline & \multicolumn{2}{|c|}{ Saat Pembayaran PPh 21} \\
\hline & \multirow{2}{*}{$\begin{array}{cr}\text { B.PPh 21 } & 5.840 .471 \\
\text { Bank } & 5.840 .471\end{array}$} & $\begin{array}{ll}\text { B.PPh } 21 \quad 5.840 .471\end{array}$ \\
\hline & & Bank $\quad 5.840 .471$ \\
\hline & \multicolumn{2}{|c|}{ Saat Pembayaran Gaji } \\
\hline & \multicolumn{2}{|c|}{ Tenaga Ahli } \\
\hline & B.Dokter $\quad 258.970 .993$ & 258.970 .993 \\
\hline & Utang PPh $21 \quad 6.605 .242$ & Utang PPh $21 \quad 6.605 .242$ \\
\hline & 252.365 .751 & 252.365 .751 \\
\hline & & payaran PPh 21 \\
\hline & 6.605 .242 & 6.605 .242 \\
\hline & 6.605 .242 & 6.605 .242 \\
\hline
\end{tabular}

Sumber: Pencatatan Akuntansi RS Vania Bogor dan Standar Akuntansi, Data diolah 
Analisis

Perhitungan,

Pencatatan,

Penyetoran dan

Pelaporan Pajak

Penghasilan 21

Pada RS Vania

Bogor Tahun

2015 - 2016

Tabel 5

Kesesuaian Pencatatan PPh Pasal 21 pada Tahun 2016

\begin{tabular}{|c|c|c|}
\hline Date & Menurut Perusahaan & Menurut Standar Akuntansi \\
\hline \multirow{13}{*}{$\begin{array}{c}\text { Januari } \\
2016\end{array}$} & \multicolumn{2}{|c|}{$\begin{array}{c}\text { Saat Pembayaran Gaji } \\
\text { Pegawai Tetap }\end{array}$} \\
\hline & $\begin{array}{ll}\text { B.Gaji } & 470.759 .260\end{array}$ & $\begin{array}{ll}\text { B.Gaji } \quad 470.759 .260\end{array}$ \\
\hline & Utang PPh 219.348 .850 & Utang PPh $21 \quad 9.348 .850$ \\
\hline & Bank $\quad 61.410 .410$ & Bank $\quad 461.410 .410$ \\
\hline & \multicolumn{2}{|c|}{ Saat Pembayaran PPh 21} \\
\hline & 9.348 .850 & B.PPh $21 \quad 9.348 .850$ \\
\hline & 9.348 .850 & 9.348 .850 \\
\hline & \multicolumn{2}{|c|}{$\begin{array}{c}\text { Saat Pembayaran Gaji } \\
\text { Tenaga Ahli }\end{array}$} \\
\hline & \multirow{2}{*}{$\begin{array}{l}\text { B.Dokter } 405.200 .868 \\
\text { Utang PPh } 2110.600 .808\end{array}$} & B.Dokter $\quad 405.200 .868$ \\
\hline & & Utang PPh $21 \quad 10.600 .808$ \\
\hline & Bank $\quad 94.600 .060$ & Bank $\quad 394.600 .060$ \\
\hline & \multicolumn{2}{|c|}{ Saat Pembayaran PPh 21} \\
\hline & $\begin{array}{cc}\text { B.PPh 21 } & 10.600 .808 \\
\text { Bank } & 10.600 .808\end{array}$ & $\begin{array}{rr}\text { B.PPh 21 } & 10.600 .808 \\
\text { Bank } & 10.600 .808\end{array}$ \\
\hline \multirow{13}{*}{$\begin{array}{l}\text { Desember } \\
2016\end{array}$} & \multicolumn{2}{|c|}{$\begin{array}{c}\text { Saat Pembayaran Gaji } \\
\text { Pegawai Tetap }\end{array}$} \\
\hline & $\begin{array}{ll}\text { B.Gaji } & 470.759 .260\end{array}$ & $\begin{array}{ll}\text { B.Gaji } & 470.759 .260\end{array}$ \\
\hline & Utang PPh 219.348 .850 & Utang PPh $21 \quad 9.348 .850$ \\
\hline & Bank $\quad 461.410 .410$ & Bank $\quad 461.410 .410$ \\
\hline & \multicolumn{2}{|c|}{ Saat Pembayaran PPh 21} \\
\hline & 9.348 .850 & B.PPh $21 \quad 9.348 .850$ \\
\hline & 9.348 .850 & 9.348 .850 \\
\hline & \multicolumn{2}{|c|}{$\begin{array}{c}\text { Saat Pembayaran Gaji } \\
\text { Tenaga Ahli }\end{array}$} \\
\hline & \multirow{2}{*}{$\begin{array}{cc}\text { B.Dokter } & 405.200 .868 \\
\text { Utang PPh } 21 & 10.600 .868\end{array}$} & B.Dokter $\quad 405.200 .868$ \\
\hline & & Utang PPh $21 \quad 10.600 .808$ \\
\hline & Bank $\quad 394.600 .060$ & Bank $\quad 396.600 .060$ \\
\hline & \multicolumn{2}{|c|}{ Saat Pembayaran PPh 21} \\
\hline & $\begin{array}{cc}\text { B.PPh 21 } & 10.600 .868 \\
\text { Bank } & 10.600 .868\end{array}$ & $\begin{array}{rr}\text { B.PPh 21 } & 10.600 .868 \\
\text { Bank } & 10.600 .868\end{array}$ \\
\hline
\end{tabular}

Sumber: Pencatatan Akuntansi RS Vania Bogor dan Standar Akuntansi, Data diolah

Berdasarkan Tabel 4 dan 5 dapat disimpulkan bahwa pelaksanaan pencatatan $\mathrm{PPh}$ Pasal 21 yang dilakukan oleh RS Vania Bogor sesuai dengan standar akuntansi yang berlaku umum. 
3. Penyetoran dan Pelaporan PPh pasal 21 Pada RS Vania Bogor

Pelaksanaan penyetoran yang dilaksanakan oleh RS Vania Bogor sudah sesuai dengan Undang-Undang KUP Nomor 28 tahun 2007 tentang Ketentuan Umum Perpajakan yakni penyetoran dilakukan sebelum tanggal jatuh tempo yang ditentukan yaitu tanggal 10 hari bulan berikutnya.

Pelaksanaan Pelaporan yang dilaksanakan oleh RS Vania Bogor juga sudah sesuai dengan Undang-Undang KUP Nomor 28 Tahun 2007 tentang Ketentuan Umum Perpajakan yakni pelaporan untuk SPT Masa dilakukan sebelum tanggal jatuh tempo yaitu tanggal 20 hari setelah akhir Masa Pajak. Ada beberapa pembetulan di dalam SPT Masa RS Vania Bogor, disebabkan karena pada periode penelitian telah terjadi pergantian karyawan di bagian divisi staff keuangan yang jumlahnya cukup signifikan.

\section{SIMPULAN DAN SARAN}

\section{Simpulan}

Berdasarkan hasil analisa perhitungan, pencatatan, penyetoran dan pelaporan Pajak Penghasilan Pasal 21 pada RS Vania Bogor Tahun 2015-2016, maka dapat ditarik simpulan sebagai berikut:

1. Kesesuaian pelaksanaan perhitungan $\mathrm{PPh}$ pasal 21 atas pegawai tetap dan tenaga ahli tahun 2015-2016 dengan PER 32/PJ/2015 dan PER 16/PJ/2016.

Pelaksanaan perhitungan PPh pasal 21 yang dilakukan oleh RS Vania Bogor telah sesuai dengan peraturan perpajakan yang berlaku.

2. Kesesuaian pelaksanaan pencatatan $P P h$ pasal 21 atas pegawai tetap dan tenaga ahli tahun 2015-2016 dengan standar akuntansi yang berlaku umum.

Pelaksanaan pencatatan PPh pasal 21 yang dilakukan oleh RS Vania Bogor telah sesuai dengan standar akuntansi yang berlaku.

3. Kesesuaian pelaksanaan penyetoran dan pelaporan $\mathrm{PPh}$ pasal 21 atas pegawai tetap dan tenaga ahli tahun 2015-2016 dengan peraturan perpajakan yang berlaku.

Pada umumnya pelaksanaan penyetoran dan pelaporan PPh pasal 21 yang dilakukan oleh RS Vania Bogor sudah sesuai dengan peraturan perpajakan yang berlaku sebagaiman dicantumkan dalam PER 32/PJ/2015 dan PER 16/PJ/2016. Namun terdapat beberapa SPT masa pembetulan di dalam pelaporan yang dilakukan RS Vania Bogor yang disebabkan karena salah dalam menghitung jumlah karyawan. Kesalahan tersebut disebabkan adanya pergantian karyawan dalam jumlah yang signifikan di bagian staff keuangan pada periode penelitian.

\section{Saran}

Untuk pegawai RS Vania Bogor yang bertanggung jawab terkait dengan $\mathrm{PPh}$ pasal 21 disarankan melakukan :

1. Perhitungan yang benar antara jumlah karyawan yang masih bekerja dan jumlah karyawan yang sudah tidak lagi bekerja di RS Vania Bogor. Pegawai tersebut harus dapat mengontrol terhadap seluruh perhitungan jumlah katyawan. Hal ini guna 
Analisis

Perhitungan,

Pencatatan,

Penyetoran dan

Pelaporan Pajak

Penghasilan 21

Pada RS Vania

Bogor Tahun

2015 - 2016 mengantisipasi terjadinya kelebihan pemotongan dan pembayaran yang diakibatkan karena adanya karyawan yang berhenti dalam tahun berjalan maupun adanya perubahan PTKP didalam tahun berjalan yang berlaku surut.

2. Apabila perusahaan sering melakukan pembetulan SPT, maka akan menjadi catatan yang kurang baik bagi perusahaan dimata Dirjen Pajak yang dapat berakibat dilakukannya pemeriksaan pajak. Meskipun pemeriksaan pajak dapat dialami oleh setiap perusahaan, perusahaan tetap harus menghindari terjadinya pemeriksaan pajak, salah satunya tertib dalam administrasi pajak.

3. Pertahankan kompetensi pegawai agar pegawai yang bersangkutan mampu mengelola perusahaan secara cermat dan benar

\section{DAFTAR PUSTAKA}

Anggriani, Tri Putri. 2010. Analisis Perhitungan Pajak Penghasilan pasal 21 atas Karyawan pada PT Connectra Utama Palembang. Palembang

Dalughu, Meyliza. 2015. Analisis Perhitungan dan Pemotongan PPh Pasal 21 Pada Karyawan PT. BPR Primaesa Sejahtera Manado. Sulawesi Utara

Mardiasmo. 2013.Perpajakan.Yogyakarta:Andi Offset.

Nugroho,Suryo Dwianto Agung. 2009. Cara Mudah Menghitung Pajak Pribadi. Jakarta: Raih Asa Sukses.

Pemerintah Indonesia. 2015. Peraturan Pemerintah Nomor 30 Tahun 2015, Tentang Gaji Pokok dan Tunjangan Pegawai Negeri SipilPP No. 13 Tahun 1980, Perubahan Dan Penambahan Atas Peraturan Pemerintah Nomor 7 Tahun 1977 Tentang Peraturan Gaji Pegawai Negeri Sipil untuk Tunjangan Anak. Jakarta

Pitriani. 2016. Analisis Pajak Penghasilan Pasal 21 atas Upah pada Dinas Pertanian Tanaman Pangan dan Holtikultura Kabupaten Hulu Sungai Utara. Kalimantan Selatan

Pohan,Chairil Anwar. 2014.Perpajakan Indonesia. Jakarta: Mitra Wacana Media.

Pratiwi, Vicky Yuliandhini. 2016. Analisis Perhitungan, Pemotongan dan Pelaporan PPh Pasal 21 Atas PNS TNI AD POMDAM V/Brawijaya Surabaya. Surabaya

Republik Indonesia. 2015. Peraturan Presiden Nomor 28 Tahun 2015, Tentang Kedudukan, Tugas dan Fungsi Ditjen Pembendaharaan. Jakarta.

Republik Indonesia. 2016. Peraturan Menteri Keuangan Nomor 102/PMK.010/2016 tentang Penetapan Bagian Penghasilan Sehubungan dengan Pekerjaan dari Pegawai Harian dan Mingguan serta Pegawai Tidak Tetap Lainnya yang Tidak Dikenakan Pemotongan Pajak Penghasilan. Jakarta.

Republik Indonesia. 2016. Peraturan Direktorat Jenderal Pajak Nomor Per-16/PJ/2016 tentang Definisi Pajak Penghasilan Pasal 21

Saputro, Januar Cahyo., Nila, Suhadak., Fidauzi, Nuzula. 2012. The Evaluation of Tax Planning on Income Tax Article 21 by Using Gross-Up Method In Form Of Coprorate Tax Savings(Study at PT. PG Kebon Agung Malang Period Of 20092012). Brawijaya

Sari,Diana. 2014.Perpajakan. Jakarta: Mitra Wacana Media.

Waluyo. 2016. Akuntansi Pajak. Jakarta: Salemba Empat. 